Cahiers $d u$ MONDE RUSSE

\section{Cahiers du monde russe}

Russie - Empire russe - Union soviétique et États indépendants

$46 / 1-2 \mid 2005$

La Russie vers 1550

\title{
КРЕСТЬЯНЕ В СОЦИАЛЬНОЙ СТРУКТУРЕ СРЕДВНЕВЕКОВОЙ РУСИ
}

\section{Vladimir A. ARAKCEEV}

\section{OpenEdition \\ Journals}

Édition électronique

URL : https://journals.openedition.org/monderusse/8785

DOI : 10.4000/monderusse. 8785

ISSN : $1777-5388$

Éditeur

Éditions de l'EHESS

Édition imprimée

Date de publication : 1 janvier 2005

Pagination : 107-114

ISBN : 2-7132-2055-6

ISSN : $1252-6576$

\section{Référence électronique}

Vladimir A. ARAKCEEV, « Крестьяне в социальной структуре средвневековой Руси », Cahiers du monde russe [En ligne], 46/1-2 | 2005, mis en ligne le 01 janvier 2007, consulté le 02 septembre 2022. URL : http://journals.openedition.org/monderusse/8785; DOl : https://doi.org/10.4000/monderusse. 8785 


\section{CAIR N}

chercher : repérer : avancer

Cet article est disponible en ligne à l'adresse :

http://www.cairn.info/article.php?ID REVUE=CMR\&ID NUMPUBLIE=CMR 461\&ID ARTICLE=CMR 4610107

\section{Крестьяне в социальной структуре средвневековой Руси}

par Vladimir A. ARAKCEEV

| Editions de l'EHESS | Cahiers du monde russe

2005/1-2 - Vol 46

ISSN 1252-6576 | ISBN 2713220556 | pages 107 à 114

Pour citer cet article :

- A. ARAKCEEV V., Cahiers du monde russe 2005/1-2, Vol 46, p. 107-114.

Distribution électronique Cairn pour les Editions de l'EHESS.

(C) Editions de l'EHESS. Tous droits réservés pour tous pays.

La reproduction ou représentation de cet article, notamment par photocopie, n'est autorisée que dans les limites des conditions générales d'utilisation du site ou, le cas échéant, des conditions générales de la licence souscrite par votre établissement. Toute autre reproduction ou représentation, en tout ou partie, sous quelque forme et de quelque manière que ce soit, est interdite sauf accord préalable et écrit de l'éditeur, en dehors des cas prévus par la législation en vigueur en France. Il est précisé que son stockage dans une base de données est également interdit. 


\section{КРЕСТЬЯНЕ В СОЦИАЛЬНОЙ СТРУКТУРЕ СРЕДНЕВЕКОВОЙ РУСИ (XIV - ПЕРВАЯ ПОЛОВИНА ХVI В.)}

Особенности государственного и общественного устройства России в XIV-XVI вв. во многом определялись природными и социальными условиями существования крестьянства. Положение крестьян в социальной структуре средневековой Руси не было устоявшимся, и дальнейшее аналитическое изучение этой проблемы невозможно без исследования прав крестьян на землю и правовых границ крестьян как социальной группы.

Для суждения о положении русских крестьян только источники XIV-XVI вв. содержат репрезентативные данные. В распоряжении историков имеется достоверные и поддающиеся истолкованию материалы - акты, писцовые книги, в большинстве своем относящиеся к новгородским землям, законодательные памятники. Характер крестьянского землевладения с наибольшей полнотой отразился в новгородско-псковских актах. Крупными документальными комплексами, в которых отразились поземельные сделки новгородско-псковских крестьян XV-XVI вв., являются 94 двинских и 27 псковских актов эпохи независимости, а также 722 двинских грамоты 1478-1560 гг. К особенностям этих документов относятся устойчивые выражения, которыми фиксируется право собственности крестьян: «вотчина», «станки», «купля». Нерушимость сделки определялось выражением «в дернь без выкупа», или «в одерень», применявшимся на территории Северо-Запада России в XIV-XVI вв.

До публикации новых псковских грамот Л. М. Марасиновой в центре внимания исследователей, интересовавшихся этой формулой, были новгородские акты. Одним из первых статью о землевладении «в одерень» написал Н. П. Павлов-Сильванский. Исследователь считал, что эта формула является общей для индоевропейских народов, и, приведя примеры из русских источников об употребления дерна в земельных делах, сопоставил их с немецкими свидетельствами, также говорящими о передаче куска дерна 
как о символическом изображении перехода участка земли во владение другого лица ${ }^{1}$.

Л. М. Марасинова обосновала концепцию, согласно которой владение землей «в одерень» означало «неограниченную какими-либо условиями собственность, предусматривающую право дальнейшего распоряжения приобретенной землей» ${ }^{2}$. «олной и безусловной собственностью» считает форму владения «в одерень» и Ю. Г. Алексеев ${ }^{3}$. В. Ф. Андреев вслед за С. Н. Валком возводит зарождение формулы «в одерень» «к доактовому периоду оформления сделки, когда дерн использовался в качестве атрибута символического обряда, сопровождавшего переход земли из рук в руки». На северо-востоке Руси, по мнению В.Ф. Андреева, аналогом формулы «в одерень» был оборот «купил... впрок без выкупа», что объясняется вытеснением обряда с дерном ритуалом хождения с иконой по межам ${ }^{4}$.

Предметом исследования в нашем докладе является термин «в одерень»социально осознанное понятие, закрепленное в специальном слове и обозначавшее правовое основание землевладения. Исследование такого понятия является составной частью более общей задачи, которая может быть сформулирована как изучение образования и внутренней организации терминологии социальных институтов по письменным источникам. Доказательность выводов в таком исследовании впрямую зависит от полноты источниковой базы: необходимо опираться по возможности на все употребления рассматриваемого слова.

Классификация 27 псковских грамот с употреблением формулы «в одерень» такова: 10 купчих, 6 духовных, 4 меновных, 3 раздельных, 2 данных, 1 ободная и 1 рядная (мировая запись). Все эти акты происходят из архивов 14 приходских церквей и монастырей: Спасо-Мирожского, Варлаама с Запсковья, св. Пятницы из Бродов, Успенского с Завеличья, Успенского с Полонища, Старо-Вознесенского, Духовского, св. Николая из Смолин, Козьмы и Демьяна из Руссок, Варваринского из-за Петровских ворот, Елизарова, Георгия с Камна, Никольского Каменноградского, Псково-Печерского.

Формула «в одерень» присутствует во всех сохранившихся псковских купчих, кроме одной - купчей посадника Максима на землю на Бойнице. Однако отсутствие клаузулы о покупке «в одерень» в данном акте может быть объяснено фрагментарностью его списка, сделанного в 1684 г. Предметом сделки в купчих являются все виды земельных владений: «земли, лес, стариска и прикреми», «село землю оромую, и хороме, и зородье, и жердье и весь запас сенные», «пожни», деревня «со всем запасом и 3 жердьем», «смердья земля и вода» и «пожня и прикремы и пень и колоду и

1. Н. П. Павлов-Сильванский, Феодализм в России, М., 1988, с. 486-492.

2. Л. М. Марасинова, Новые псковские грамоты XIV-XV вв., М., 1966, с. 125-126.

3. Ю. Г. Алексеев, Псковская судная грамота и ее время, Л., 1980, с. 98.

4. В. Ф. Андреев, Новгородский частный акт XII-XV вв., Л., 1986, с. 89-90. 
полесья», «два места вода... и седенье и запас дву мест», «нива» 5 . Социальный статус продавцов определен лишь в одном акте - купчей Григория и Федора на землю сельских смердов в Лисьях. Социальный статус покупателей известен в двух случаях, когда покупателями были служилый литовский князь и псковский купец. О статусе контрагентов большинства грамот можно лишь догадываться.

Вторая группа актов - духовные. Из шести духовных грамот, в которых имеется формула «в одерень», три были составлены представителями социальных верхов Пскова - вдовой князя Акилиной, Никитой Ховом и Ульяной. Недвижимость, передаваемая Никитой Ховом, состояла из семи объектов, среди которых два городских двора и четыре села в разных погостах. Но «в одерень» по духовной Хова передавались лишь те села и дворы, которые оставались во владении детей завещателя. Три села передавались монастырям непосредственно или после «кормли» наследников завещателя, и в этом случае оборот «в одерень» не употреблялся. Духовные Анцыпора, Семиона и Павла вряд ли были составлены представителями верхов общества: в них завещаются единичные объекты (пустошь, село земли). Завещателями в данном случае могли быть как мелкие вотчинники, так и крестьяне. В трех духовных оборот «в одерень» не применялся, и в одном случае можно предположить, почему в духовной земля передается без сопровождения формулы «в одерень». По духовной старосты Вознесенскому монастырю передается «Иванова земля» с угодьями, которая, видимо, являлась выморочной ${ }^{6}$. Староста не мог передать «в одерень» землю, которой он не владел и претензии на которую могли быть предъявлены «племенем» прежнего владельца.

Обратимся к типологически сходному, новгородско-двинскому материалу. С XIII в. новгородским актам знаком оборот «в одерень», первое бесспорное упоминание которого содержится в духовной Климента, передавшего в 1255-1257 гг. два села «одерьнь святому Гергью». В 1333-1342 гг. «одерень себе и своим детем» купил Тайбольскую землю Лука Варфоломеевич. В Новгороде, подобно Пскову, «в одерень» покупали городские дворы, как это сделал Максим Фалелеев во второй четверти XV в. Наиболее поздний акт с упоминанием оборота «в одерень», относящийся к собственно новгородским (будущим пятинным) землям, датируется 60-ми 70-ми годами XV в. ${ }^{7}$

Двинские акты, в которых употребляется оборот «в одерень», являются наиболее крупным документальным комплексом эпохи независимости Новгорода, насчитывающим более 140 купчих, духовных, данных и рядных

5. Л. М. Марасинова, указ. соч., с. 46-64.

6. Там же, с. 53.

7. Грамоты Великого Новгорода и Пскова, М. - Л., 1949 (Далее - ГВНП), с. 162, 175, 290; В. И. Корецкий, «Вновь открытые новгородские и псковские грамоты XIV-XV вв.», Археографический ежегодник за 1967 год, М., 1969, с. 285. 
грамот. Самый ранний двинской акт датирован концом XIV в. Именно двинские грамоты позволяют проверить некоторые гипотезы, касающиеся оборота «в одерень». А. И. Копанев писал о том, что формулы купчих «в одерень» и «впрок без выкупа» свидетельствует «о неограниченных правах нового владельца на приобретенную землю». Отождествив оборот «в одерень» с формулой «впрок без выкупа» из купчих северо-восточной Руси, В. Ф. Андреев также пришел к выводу о «незыблемости владения купленной недвижимостью», гарантированной «дерноватыми» грамотами ${ }^{8}$.

Единичные акты, тем не менее, свидетельствуют о реальной возможности родового выкупа проданной «в одерень» вотчины. В 50-х годах XV в. Андрон Леонтьевич выкупил тоню на берегу Белого моря - «отцину свою... из дерну и $з$ дерною грамотою». Любопытно, что в заключении выкупной грамоты стоит клаузула, традиционная для купчих: «А выкупил собе и своим детем одерень». Очевидно, что в данном случае оборот «в одерень» вовсе не гарантировал первому покупателю незыблемость сделки.

Формула «в одерень» активно использовалась в актах двинских крестьян и своеземцев и в XVI в. В. Ф. Андреев, основываясь на факте вытеснения формулы «одерень» из новгородских и обонежских купчих к середине XV в., сделал вывод, что «процесс выпадения доактовых элементов из формуляра новгородских и обонежских купчих зашел в XV в. дальше, чем на Двине, а значит, новгородские купчие прошли... более долгий путь развития, чем двинские, что в свою очередь указывает на более высокий уровень поземельных отношений в центре новгородской земли, нежели на ее окраинах» ${ }^{10}$. Такой вывод вызывает определенные сомнения, так как по ходу интерпретации фактов рабочая гипотеза выступает в качестве аргумента. Вряд ли «выпадение» таких формул, как «одерень» происходило только путем эволюции актового формуляра. В отличие от двинских актов, мы располагаем единичными документами подобного типа, относящимися к собственно новгородским землям (шесть актов XIII-XV вв.), так что в данном случае вполне возможна аберрация, вызванная недостатком источников в одном случае и их относительным обилием в другом. Но даже немногие сохранившиеся акты свидетельствуют, что формула «одерень» и в собственно новгородских землях используется вплоть до конца 1470-х годов. В купчей Есипа Ивановича на землю на Вишере, датированной В. Л. Яниным 60-ми - 70-ми годами XV в., оборот «одерень» употребляется дважды - и при констатации факта внесения денег, и в заключительной клаузуле ${ }^{11}$.

$* * *$

8. А. И. Копанев, «Крестьянское землевладение Подвинья в XVI в.», Проблемь крестьянского землевладения и внутренней политики России, Л., 1972, с. 117; В. Ф. Андреев, Новгородский частный акт, с. 89-90.

9. ГВНП, с. $192-193$.

10. В. Ф. Андреев, указ. соч., с. 92.

11. ГВНП, с. 175; В. Л. Янин, Новгородские акты ХII-ХV вв., М., 1991, с. 223-225. 
Исчезновение формулы «одерень» в новгородских актах этого времени было вызвано, скорее всего, сменой всего документооборота в результате инкорпорации Новгорода в состав Москвы. Распространение на новгородские пятины верховной собственности великого князя на землю привело к прекращению документально оформленного процесса куплипродажи земли. Именно тогда появляется новый вид землевладения оброчные земли, находившиеся в собственности великого князя. На новгородском севере в разряд оброчных земель великого князя («княжщинных») были переведены лишь отдельные владения в нижнем течении Двины и по берегу Белого моря. Основная масса земель на Двине продолжала оставаться чернокунскими, а их владельцы до 1560-х годов распоряжались своей землей на прежних основаниях и использовали при составлении актов старый формуляр эпохи независимости.

Переход оброчных земель из рук в руки фиксировался в отступных (посильных) грамотах, подавляющее большинство которых происходит из крестьянских архивов Двинского уезда. Оброчные земли относительно легко вводились в торговый оборот, хотя сделка осуществлялась в завуалированной форме: землю не продавали, а «поступались» ею. Известны случаи заклада оброчной земли «в кабале в рубле». Известны посильные грамоты, относящиеся и к уездам Северо-Восточной Руси: Великоустюжскому и Балахнинскому, где также источниками фиксируются оброчные земли. Судьба оброчных земель в дальнейшем была различной: оброчные земли Двинского уезда стали частью черносошных земель, а оброчные земли Балахнинского уезда составили дворцовые волости. Описанные различия в принципах мобилизации земли, как можно предположить, свидетельствуют о двух тенденциях в эволюции крестьянского землевладения: московской, для которой была характерна верховная собственность государства на землю, и новгородской, которая характеризовалась значительно более широкими правами крестьян на землю. Еще в 1547-1548 гг. в финансовых документах двинских крестьян различались «княжщинные» и «чернокунские» сохи, и только в ходе административно-фискальных преобразований 1550-х годов «княжщинные» деревни вошли в состав черносошных земель.

Обращение к новгородско-двинским актам позволяет предположить, что зона распространения формулы «одерень», охватывавшая территорию от Пскова до Двины, представляла собой одновременно регион особых отношений в сфере землевладения, характеризующийся меньшим влиянием государства и большей свободой в сфере мобилизации земли, нежели на территории Волго-Окского междуречья. В Псковском государстве владение землей «в одерень» также существует до инкорпорации в состав Москвы. Судя по сохранившимся актам, их состав после 1510 г. резко контрастирует с дошедшими до нас актами эпохи независимости. Абсолютное большинство псковских грамот, сохранившихся от времени до инкорпорации - частные акты, фиксировавшие сделки с землей. После 1510 г. преобладают 
жалованные грамоты, затем появляется делопроизводственная документация приказных учреждений. Отсутствие частных земельных актов в Пскове после 1510 г. свидетельствует о том, что присоединение к Москве привело к введению в Пскове верховной собственности на землю государства в лице великого князя. Логично заключить, что независимый Псков не знал верховной собственности на землю, и именно с земельными порядками вечевых государств связано появление и использование оборота «в одерень».

Когда формула «в одерень» могла войти в формуляр псковских актов? В псковских духовных грамотах действительно, как показал Г. В. Семенченко, наличествуют архаические черты, что говорит об относительно раннем становлении их формуляра. Первая черта - это оборот «учиних ряд», который заменяет формулу о составлении рукописания. Именно в X-XII вв. слово «ряд» служило, в частности, для обозначения завещательного распоряжения. Вторая черта также свойственна актам XII в. - это санкция за нарушение завещания в виде суда с нарушителем грамоты перед Богом. Таким образом, формуляр псковских завещаний сложился очень рано - не позднее XII в. ${ }^{12}$ Не намного позднее должен был сложиться и формуляр других разновидностей актов, в частности, раздельных грамот. В раздельной Ждановых детей с игуменьей Старо-Вознесенского монастыря употреблен столь же архаичный оборот «сеи дель ряд» ${ }^{13}$. Раннее складывание формуляра псковских актов позволяет именно с этим фактом связать универсальное употребление формулы «в одерень».

О том, что владение землей «в одерень» «не было монопольным правом или привилегией какой-либо социальной группы», писала Л. М. Марасинова. Она, однако, полагала, что приобретатели земли не могли быть крестьянами, на чью долю оставалось только продавать свои земли, превращаясь в изорников. Думается, что до настоящего времени в нашем распоряжении нет данных, позволяющих сколь-нибудь уверенно обосновать социальную стратиграфию непривилегированной части сельского общества Псковской земли. Мы не можем провести четкую границу между мелкими вотчинниками-земцами и крестьянами-чернокунцами. Такие покупатели, как Антон с братьями, Власий, Никон и Анфим вполне могли быть как вотчинниками-земцами, так и чернокунцами ${ }^{14}$. Землями «в одерень» могли владеть все категории населения Псковского государства, кроме холопов. Такую интерпретацию косвенно подтверждает и западноевропейский материал. Н. П. Грацианский писал, что в средневековых актах «социальная квалификация» собственника земли «в подавляющем большинстве случаев отсутствует совершенно, и даже лица графского рода сплошь и рядом

12. Г. В. Семенченко, «Византийское право и оформление русских завещаний XIV-XV вв.», Византийский временник, т. 46, М., 1986, с. 172.

13. Л. М. Марасинова, указ. соч., с. 54.

14. Там же, с. $51,56,60,61$. 
фигурируют в бургундских грамотах X-XI вв. с одними лишь личными именами» 15 .

Ряд фактов не позволяют принять гипотезу о владении землей «в одерень» как полной и безусловной собственности. По духовной Павла движимое имущество («живот») и недвижимость («село земли») переходят в пожизненное владение его вдовы Федосьи. Село переходит к ней, используя терминологию других актов, «в кормлю» («пить ей и есть со отчине моей до ея живота»). Движимое имущество («живот») переходит «в одерень», но тут же выясняется, что она не может распорядиться самостоятельно «животом», который должны продать и раздать в милостыню душеприказчики Павла ${ }^{16}$.

Значение термина «одерень», как нам кажется, отчасти проясняет список с ободной грамоты на земли троицкой слободы конца XV - начала XVI в. B отрывке этого акта, имеющего государственное происхождение, помимо терминов «в одерень» и «дерноватая грамота», трижды употребляется термин «дерн» («дерен»). Из ободной грамоты ясно, что в одном «ободе» с землями, пожалованными слободе, находятся частные владения (лядины, пожни и нивы) жителей Изборской волости и псковичей, с которых «Господин Пскову... дерну не имал» ${ }^{17}$. Дерн, таким образом, приобретает в этом акте значение государственного налога, или совокупности налогов, которые взимаются с государственных земель, находящихся, в частности, в пользовании слобожан. Формула «в одерень», по нашему предположению, как раз и должна была символизировать частное владение лица или рода, свободное от особого государственного обложения, которое в Пскове носило название «дерна». Данная гипотеза может служить лишь одним из подступов к сложнейшей проблеме изучения социальной структуры средневековой Руси.

Выявленные региональные различия в крестьянском землевладении разнообразие правовых режимов на территориях разной юрисдикции заставляют поставить вопрос о правовых границах крестьян как социальной группы. Большинство исследователей истории русского крестьянства считали, что сельское население Руси в XV-XVI вв. можно считать сословием. Но дают ли источники возможность столь безоговорочной интерпретации? Очевидно, что в сознании современников крестьяне не осознавались как закрытое, обособленное сословие; напротив, в крестьяне можно было «порядиться», приобретя новый статус, либо «отказаться» и из крестьянства, и от статуса. Термин «посадские люди» употребляется в законодательных актах с конца XV в. (Белозерские уставная и таможенная грамоты). Но до середины XVI в. правовые границы между «крестьянами городскими и волостными» были расплывчаты. Существовали лимитрофные корпорации, как, например, слободчики на вольном промысле (солевары),

15. Н. П. Грацианский, Бургундская деревня в Х-ХІІ столетиях, М. - Л., 1935, с. 46. 16. Л. М. Марасинова, указ. соч., с. 57-58.

17. Там же, с. 71-72. 
или слободчики служебной организации (бобровники, кирпичники, колесные мастера, ямщики). Специфическим было и положение монастырских городских слобод, жители которых по Стоглаву (гл. 98) имели право уходить от владельца, подобно крестьянам, в Юрьев день.

Таким образом, крестьян XV - первой половины XVI в. можно представить как холистическую общность, отдельные страты которой были подчинены разным сюзеренам и различались именно по своей владельческой принадлежности. Ключевое значение в образовании сословия крестьян имели реформы местного управления середины XVI в., результатом которых было обособление городских и сельских тяглых миров. Но и после административно-фискальных преобразований 1550-х годов правовое положение различных категорий крестьян сблизилось не сразу. Черносошные крестьяне наряду с посадскими людьми получили право участия в земском самоуправлении, в то время как частновладельческие крестьяне постепенно отстраняются даже от участия в волостных судах.

Псковский государственный педагогический университет

arakk@rambler.ru 